\title{
Who Do European Parties Represent? How Western European Parties Represent the Policy Preferences of Opinion Leaders
}

\author{
James Adams University of California, Davis \\ Lawrence Ezrow University of Essex
}

\begin{abstract}
Several recent studies explore how American politicians represent the policy views of subconstituencies within the electorate. We extend this perspective to 12 West European democracies over the period 1973-2002 to examine how mainstream parties responded to electoral subconstituencies. We find that parties were highly responsive to the views of opinion leaders, i.e., citizens who regularly engaged in political discussions and persuasion; by contrast we find no evidence that other types of voters substantively influenced parties' policy programmes. We also identify significant time lags in mainstream parties' responses to opinion leaders' policy beliefs. Our findings have interesting implications for subconstituency representation, for understanding parties' internal policymaking processes, and for spatial modeling.
\end{abstract}

I $\mathrm{n}$ the past decade, research on U.S. politics has focused on two important topics in the field of representation: dynamic representation (Erikson, MacKuen, and Stimson 2002; Stimson, MacKuen, and Erickson 1995) and subconstituency representation (Bartels 2005; Gilens 2005; Griffin and Newman 2005; Highton 2006). Collectively, these works suggest that American political elites adjust their policies in response to variations in the "public mood," and, furthermore, that elected officials are disproportionately responsive to electoral subconstituencies composed of the affluent, the highly educated, and the politically involved. Here we focus on European politics, and ask: Are large, mainstream, European parties disproportionately responsive to opinion leaders, i.e., to the relatively narrow subconstituency of citizens who regularly discuss politics and who attempt to persuade others to change their viewpoints? And, are parties' dynamic responses to opinion leaders mediated by time?

Our empirical analyses suggest that the answer to both of the above questions is yes. Mainstream European parties indeed appear disproportionately responsive to opinion leaders (in fact we find no evidence that parties respond at all to other segments of the electorate), and, furthermore, we find evidence that time mediates this relationship in an unexpected and important manner: specifically, parties respond dynamically not only to current shifts in opinion leaders' policy preferences, but also to lagged shifts in these citizens' preferences. The latter finding plausibly reflects the time-consuming deliberations involved in the production of parties' policy programmes.

We identify two reasons why our findings are important. First, there are normative consequences for our empirical finding of representational inequality in Western Europe. By representational inequality we mean that mainstream parties appear far more responsive to the policy preferences of some electoral subconstituencies than to others. Thus our findings call into question a very basic notion of democratic representation raised by Dahl, that citizens be "considered as political equals" $(1971,1)$.

Second, our finding of representational inequality has important substantive consequences for mainstream parties' positioning. This is because we show that opinion leaders' policy preferences are, on average, substantially to the left of the general electorate. This suggests that political elites' greater responsiveness to opinion leaders' viewpoints substantially influences parties' policy programmes. 


\section{Hypotheses}

Several recent studies on American politics explore whether elected officials are disproportionately responsive to the policy preferences of subconstituencies composed of the following groups: the affluent (Bartels 2005; Gilens 2005), the politically knowledgeable (Highton 2006), and the politically active (Griffin and Newman 2005). These studies conclude that legislators' voting records and government policy outputs appear disproportionately responsive to these subconstituencies' policy preferences.

In extending the above research perspective from the United States to Western Europe, we focus on an electoral subconstituency that combines the attributes of the politically knowledgeable and the politically active: namely, opinion leaders, i.e., citizens who frequently discuss politics with their friends, family, and/or coworkers, and who moreover report that they sometimes persuade others to adopt their political viewpoints. ${ }^{1}$ Our focus on opinion leaders, as opposed to affluent citizens, is driven by our reasoning that the extensive public financing of political parties across western Europe-financing that in most cases greatly exceeds the public funds available to U.S. politicians, as a proportion of political expenditures (see, e.g., Farrell and Webb 2000)—diminishes European elites' incentives to cater to wealthy constituents, compared to the incentives that American politicians confront. By contrast, for reasons discussed below, we expect European politicians (in common with their American counterparts) to respond disproportionately to politically involved and active citizens. $^{2}$

For the elite side of our representational study we focus on the policy programmes published by the major, mainstream, political parties in Western Europe. By mainstream parties, we refer to parties such as Labor, Socialist, Social Democratic, Liberal, Conservative, and Christian Democratic parties that have dominated European politics for most of the postwar period. Our decision to focus on the policies of political parties as a whole, as opposed to the behavior of individual legislators as in the U.S.-based studies discussed above, reflects the fact that the disciplined party-line voting in parliaments outside

\footnotetext{
${ }^{1}$ Below we provide a more detailed discussion of our definition of opinion leaders.

${ }^{2}$ In supplementary analyses that we summarize in footnote 12 below, we find no evidence that European parties respond disproportionately to affluent or highly educated citizens, independently of their responsiveness to opinion leaders.
}

the United States implies that political parties are the primary vehicle for political representation in Western Europe. As Sartori argues, "Citizens in Western democracies are represented through and by parties. This is inevitable" (1968, 471; emphasis in original). We analyze the behavior of mainstream partiesthereby excluding from our analyses smaller, niche parties, such as green, radical right, and communist parties-because previous studies conclude that niche parties are far less responsive to public opinion than are mainstream parties, and, furthermore, that many niche parties do not take meaningful positions along the Left-Right dimension that is our empirical focus. ${ }^{3}$ For those unpersuaded by these arguments, however, we note that all the substantive conclusions we report below are unchanged when we expand our analyses to include niche parties.

\section{Hypotheses on Opinion Leaders and Subconstituency Representation}

There are several reasons why European politicians (in common with their American counterparts), may be disproportionately responsive to the policy viewpoints of opinion leaders. Although our empirical focus is on whether, not why, elites respond disproportionately to opinion leaders, we briefly elaborate these considerations here. The first reason, which we label the communication process, is that to the extent that party elites make good-faith efforts to represent voters' policy beliefs, elites may respond disproportionately to opinion leaders because these citizens are more likely to have meaningful policy attitudes and political ideologies, and also because opinion leaders are more likely to communicate their views to elites. ${ }^{4}$ As Verba argues, "political activity is the means by which citizens make their needs and preferences known to governing elites and induce them to be responsive" (2003, 663; also quoted in Griffin and

\footnotetext{
${ }^{3}$ For evidence that niche parties are less responsive to public opinion than are mainstream parties, see Adams et al. (2006). For arguments that niche parties (with the exception of communist parties) do not take meaningful positions along the classic LeftRight economic dimension, see, e.g., Meguid (2005, 2008).

${ }^{4}$ With respect to the first point, public opinion researchers dating back at least to Converse (1964) have argued that, even on policy dimensions that are highly salient to elites, some electoral subconstituencies lack meaningful opinions, and public opinion researchers are nearly unanimous that nonattitudes are less common among the subconstituency of well-informed, politically engaged citizens (see, e.g., Converse 1964; Zaller 1992). With respect to the second point, elites will have an easier time representing the views of citizens who actively communicate their opinions, a subconstituency that is likely to feature a disproportionate share of opinion leaders.
} 
Newman 2005, 1207). Second, parties' policy positions may reflect opinion leaders' beliefs because opinion leaders influence the selection of party elites to a greater extent than do rank-and-file voters-an effect we label the selection process. In particular, to the extent that opinion leaders turn out to vote at higher rates than other segments of the electorate, and that their voting decisions are more policy-based than the decisions of rank-and-file voters (an effect that is in turn related to the higher incidence of meaningful policy attitudes among opinion leaders), we might expect that parties' policy positions will disproportionately reflect opinion leaders' viewpoints. ${ }^{5}$

The third causal process we identify, which we label the office-seeking process, is one where political parties tailor their policies to opinion leaders' beliefs in pursuit of electoral support. Such elite calculations plausibly revolve around the factors discussed above: namely, that to the extent that opinion leaders are more likely to turn out to vote, to have meaningful policy attitudes, and to be aware of parties' policy positions, parties gain electoral benefits from responding to opinion leaders' policy beliefs that are disproportionate to opinion leaders' numbers in the electorate. Furthermore, parties may privilege opinion leaders' viewpoints because party elites believe that these citizens influence other voters' decisions, since (by definition) opinion leaders are those who report that they discuss politics and engage in political persuasion. This perspective ties in with Downs' (1957, 228-30) argument that less-informed citizens can minimize the costs of acquiring political information by acquiring it from more politically engaged individuals, i.e., opinion leaders, and it also connects with empirical findings from the political communication literature that in situations where rank-and-file citizens discuss politics, the "preferences of politically expert discussants are weighted more heavily in the collective deliberations of democratic politics" (Huckfeldt 2001, 436; italics added). (Below

\footnotetext{
${ }^{5}$ We note that this selection effect may be muted in Proportional Representation-based voting systems where voters cast votes for parties, not candidates. However many PR-based systems (including several that we analyze empirically below) give voters opportunities to cast votes for candidates as well as for parties, so that voters can influence the composition of a party's parliamentary delegation. In addition we note that in recent years an increasing number of European parties, notably the British Conservatives, the French Socialists, and UMP, and the L'Unione coalition in Italy, have instituted nation-wide primary elections in which rank-and-file party members select their party's leader and/or their party's presidential candidate-a selection process that gives opinion leaders (and other voters) the opportunity to influence parties' policies prior to the general election stage.
}

we present evidence that the survey respondents that we label opinion leaders are more politically knowledgeable than other voters.)

The considerations discussed above motivate our first hypothesis, which we label the Opinion Leadership Hypothesis:

H1: Parties are more responsive to the policy views of opinion leaders than to the views of other members of the electorate.

We might expect that-in addition to responding to voters' current policy shifts-parties will also respond to public opinion shifts from earlier time periods. Budge (1994; see also Kitschelt 1994; McDonald, Mendes, and Budge 2004), for instance, argues that parties operate under circumstances of radical uncertainty that limit their abilities to respond flexibly to short-term shifts in outside events or conditions, whether these relate to public opinion (our empirical focus) or to social and economic conditions. Furthermore, the intraparty process of developing policies may cause parties' policy positions to lag considerably behind current conditions. For most Western European parties the task of writing the party manifesto is undertaken by party research departments and committees over a two-to-three-year period, during which drafts of the party's policy positions are circulated through various committees and even down to consultations with grassroots supporters and up to approval by party conferences (see Budge 1994; Budge et al. 2001). We also note that to the extent that the selection process outlined above is operating, this would also explain interelection time lapses between opinion leader shifts and subsequent party policy shifts. These considerations motivate our second hypothesis, which we label the Lagged Party Response Hypothesis:

H2: To the extent that parties lag in responding to public opinion, they respond disproportionately to the lagged shifts of opinion leaders' beliefs.

\section{Are Opinion Leaders Different from Other Voters?}

We note that the communication, selection, and office-seeking processes described above revolve around the commonsense observation that opinion leaders are more politically engaged than rank-andfile citizens. Namely, these processes imply that opinion leaders are more likely to have meaningful policy attitudes, to be aware of parties' policy 
positions, and to participate in politics by turning out to vote, contributing resources to political parties, and communicating their views to party elites. Here we present summary statistics that bear on these issues, and we also compare opinion leaders' policy preferences to those of nonopinion leaders. These latter analyses are important because if the preferences of these two groups do not differ, then political elites cannot respond differentially to these subconstituencies.

Our longitudinal measures of public opinion and of political engagement derive from Eurobarometer surveys dating from 1973 (the first year that the LeftRight self-placement item appears on the Eurobarometer survey) ${ }^{6}$ until 2002 (the last year for which the public opinion data is available in the Mannheim Eurobarometer trend file). The surveys ask approximately 2,000 respondents in each country in each year to place themselves on a 1-10 Left-Right ideological scale (where 1 indicates an extreme leftwing position and 10 is extreme right), ${ }^{7}$ and the surveys also include questions about political participation relating to voting behavior and party membership. We use these items in conjunction with the opinion leader index to calculate the Left-Right preferences and the degree of political engagement for respondents classified as opinion leaders, and we compare these figures to those for other respondents (i.e., those who are not opinion leaders). The opinion leader index is constructed from Eurobarometer respondents' responses to two survey questions measuring levels of political discussion and persuasion. ${ }^{8}$ Specifically, Eurobarometer respondents are classified as opinion leaders if they report that they engage in political discussion "frequently" and that they persuade their friends, relatives, or coworkers "often" or "from time to time." The mean Left-Right self-

\footnotetext{
${ }^{6}$ For the public opinion data, we relied on the Mannheim Eurobarometer Trend File, 1970-2002 (Schmitt and Scholz 2005) which has compiled the Eurobarometer surveys for the time period under investigation.

${ }^{7}$ The Eurobarometer surveys ask, "In political matters, people talk of 'the left' and 'the right.' How would you place your views on this scale?" The Eurobarometer surveys do not consistently ask questions on specific policy dimensions, so that the LeftRight item is the only one that is usable in our time-series analyses of public opinion.

${ }^{8}$ The survey item measuring political discussion is phrased "When you get together with friends, would you say you discuss political matters frequently, occasionally or never?," and respondents' persuasiveness is measured based on the question, "When you (yourself) hold a strong opinion, do you ever find yourself persuading your friends, relatives or fellow workers to share your views? Does this happen often, from time to time, rarely or never?"
}

placements and the levels of participation for "other voters" are calculated for the respondents scoring in the remaining categories of the opinion leadership index. We note that in every country in our study "other voters" greatly outnumber opinion leaders, with the proportion of opinion leaders ranging from a high of just $25.7 \%$ in Greece to a low of $5.5 \%$ in Portugal. The average proportion of opinion leaders across the countries is about $13 \%$.

Tables 1-2 report summary statistics on opinion leaders' levels of political engagement, compared to other voters. These summary statistics are computed on the full set of Eurobarometer surveys over the 1973-2002 period, so that they encompass a huge number of respondents-over 40,000 per country, except for Luxembourg. ${ }^{9}$ Table 1 reports the proportions of opinion leaders versus other voters who were unwilling or unable to place themselves on the LeftRight scale (columns 1-2), along with the average proportion of each subconstituency that was unable or unwilling to place the major political parties on this scale (columns 3-4). ${ }^{10}$ In every country the incidence of nonresponse was significantly lower for opinion leaders than for other voters. These data suggest that opinion leaders are more likely to possess meaningful political ideologies and also that they are more knowledgeable about the parties' ideological positions.

Table 2 reports statistics on political participation. Columns 1-2, which report the proportions of Eurobarometer respondents who stated that they did not vote in the previous national election, show consistently lower reported abstention rates among opinion leaders. ${ }^{11}$ The Eurobarometer surveys do not include consistent over-time questions on other

${ }^{9}$ For Luxembourg, our summary statistics encompass over 29,000 respondents. We note that the one exception to this generalization are the statistics on respondents' party placements (see columns 3-4 of Table 1), which are based on a single Eurobarometer survey conducted in 1989 (the only survey that contained the party placement item), which surveyed roughly 1,000 respondents per country.

${ }^{10}$ In the case of France, for instance, the proportions of opinion leaders who were unable or unwilling to place the major French parties were as follows: unwilling to place the Communist Party: 1.6\%; Socialists: 0\%; UDF: 2.4\%; RPR: $8.0 \%$; National Front: $1.6 \%$. The average across the five parties is $2.6 \%$, which is the percentage reported for France in column 3 of Table 1. The proportions for other voters were similarly computed.

${ }^{11}$ We note that Eurobarometer respondents' reported turnout decisions are not validated and that consequently the reported abstention rates in the Eurobarometer surveys are substantially lower than the observed abstention rates in the national elections in these countries. 
TABLE 1 Eurobarometer Respondents' Left-Right Self-placements, and Party Placements

\begin{tabular}{|c|c|c|c|c|}
\hline & \multicolumn{2}{|c|}{$\begin{array}{c}\% \text { of respondents who are unwilling or } \\
\text { unable to self-place }\end{array}$} & \multicolumn{2}{|c|}{$\begin{array}{c}\% \text { of respondents who are unwilling or } \\
\text { unable to place the parties }\end{array}$} \\
\hline & Opinion Leaders (1) & Other Voters (2) & Opinion Leaders (3) & Other Voters (4) \\
\hline France & 6.7 & 15.9 & 2.6 & 10.9 \\
\hline Belgium & 10.0 & 21.4 & 22.3 & 41.7 \\
\hline Netherlands & 3.1 & 8.4 & 5.0 & 16.5 \\
\hline Italy & 9.6 & 23.5 & 1.7 & 13.5 \\
\hline Luxembourg & 10.3 & 24.0 & 12.3 & 29.5 \\
\hline Denmark & 3.0 & 8.8 & 4.4 & 13.6 \\
\hline Ireland & 7.9 & 18.3 & 6.7 & 19.3 \\
\hline Great Britain & 4.3 & 11.6 & 23.7 & 37.7 \\
\hline Greece & 9.9 & 23.7 & 9.2 & 26.4 \\
\hline Spain & 10.2 & 25.4 & 11.0 & 27.8 \\
\hline Portugal & 12.2 & 24.1 & 35.2 & 43.0 \\
\hline Average & 7.9 & 18.6 & 15.6 & 25.2 \\
\hline
\end{tabular}

${ }^{1}$ The percentages in columns 3-4 represent the proportions of respondents who are unwilling to place each major party, averaged across the major parties in the system. Major parties are defined as those that were pictured in the country-by-country spatial maps presented in Chapter 1 in Budge et al. (2001).

Notes: The percentages reported in columns 1-2 are summary statistics based on the full set of Eurobarometer surveys administered between 1973 and 2002. The average number of respondents per country that were used to compute these figures was over 50,000. The percentages reported in columns 3-4 were computed based on the results of the 1989 Eurobarometer survey (Eurobarometer 31A), the only survey that contained the party placement item. The number of responses per country in this survey was roughly 1,000 .

forms of political participation; however, columns 3-4 report summary statistics on party membership, an affiliation that is linked to other forms of political participation such as contacting political elites and working on behalf of political parties (Scarrow 2000). The results show that in every country in our study, opinion leaders were far more likely to report party membership than were rank-and-file voters. ${ }^{12}$

Next, we present evidence on the differences in the ideological preferences of opinion leaders versus rank-and-file voters. Figure 1 compares these groups' ideological tendencies by graphing the differences in the mean Left-Right self-placements of rank-and-file voters versus those of opinion leaders, calculated across all respondents who self-placed on this scale. Since ideology is scaled so that right-wing positions are higher, the positive values displayed in the figure indicate that, on average, rank-and-file voters located to the right of opinion leaders in every country in our study except Austria. All of these differences are statistically significant, and they are also substantively significant: in all countries except for Austria, Ireland,

\footnotetext{
${ }^{12}$ With respect to sociodemographic characteristics, we found that opinion leaders were modestly better educated and more affluent than other voters, but that these groups had virtually identical age distributions. Footnote 24 below summarizes the results of sensitivity analyses that suggest that our substantive conclusions on parties' disproportionate responsiveness to opinion leaders is not due to these education- and income-related differences.
}

and Portugal, the mean ideological placements of opinion leaders are more than 0.25 units to the left of rank-and-file voters' mean placements, along the 10-point Left-Right scale. ${ }^{13}$

In toto, the summary statistics reported above support the hypothesis that opinion leaders are more politically engaged than rank-and-file voters, in that they are more likely to express their ideological positions, to be aware of parties' positions, to turn out to vote, and to formally affiliate with political parties. Furthermore, in every country in our study (except Austria) opinion leaders' ideological positions are to the left of rank-and-file voters' positions, so that to the extent that political elites are disproportionately responsive to opinion leaders, this

\footnotetext{
${ }^{13} \mathrm{We}$ conducted additional analyses (available upon request) which suggested that opinion leaders' self-placements are also substantially more dispersed than those of other voters, i.e., in every country in our study the standard deviation of opinion leaders' Left-Right self-placements exceeded the standard deviation for other voters. Related analyses found that, among supporters of left-wing parties, opinion leaders' mean Left-Right placements were sharply to the left of other voters, but that this pattern did not extend to the supporters of centrist and rightwing parties. To the extent that parties respond to the dispersion of voters' policy preferences (see Ezrow 2007) or to the preferences of their supporters (see Adams, Merrill, and Grofman 2005; Dalton 1985), as opposed to responding to the mean or median voter position, these differences may have important implications for party positioning. We thank an anonymous referee for suggesting these analyses.
} 
TAble 2 Eurobarometer Respondents' Reported Political Participation, 1973-2002

\begin{tabular}{|c|c|c|c|c|}
\hline & \multicolumn{2}{|c|}{$\begin{array}{l}\% \text { of respondents who report they } \\
\text { did not vote in the last election }\end{array}$} & \multicolumn{2}{|c|}{$\begin{array}{l}\% \text { of respondents (or a household member } \\
\text { who are party members }\end{array}$} \\
\hline & Opinion Leaders (1) & Other Voters (2) & Opinion Leaders (3) & Other Voters (4) \\
\hline France & 8.5 & 12.1 & 14.4 & 2.0 \\
\hline Belgium & 2.9 & 4.7 & 27.5 & 6.2 \\
\hline Netherlands & 3.6 & 8.6 & 15.7 & 5.9 \\
\hline Italy & 4.5 & 6.7 & 28.6 & 6.0 \\
\hline Luxembourg & 6.6 & 11.9 & 27.2 & 10.0 \\
\hline Denmark & 3.0 & 4.7 & 20.8 & 7.7 \\
\hline Ireland & 5.3 & 10.0 & 14.1 & 3.1 \\
\hline Great Britain & 6.3 & 10.5 & 14.7 & 4.3 \\
\hline Greece & 3.9 & 7.8 & 17.8 & 5.2 \\
\hline Spain & 17.2 & 21.6 & 12.8 & 2.1 \\
\hline Portugal & 9.3 & 12.4 & 10.5 & 2.2 \\
\hline Austria & 6.3 & 10.7 & - & - \\
\hline Average & 6.5 & 10.1 & 18.6 & 5.0 \\
\hline
\end{tabular}

Notes: The percentages reported in the table are summary statistics based on the full set of Eurobarometer surveys administered between 1973 and 2002. The average number of respondents per country that were used to compute the figures on voter turnout was over 25,000 (except for Austria, which is based on just over 4000 respondents), and over 10,000 for party membership. Party membership figures are based on respondents who reported that they or a household member are political party members. We do not report membership figures for Austria, who first appear in the survey in 1994, because the item does not appear on the Eurobarometer after 1990.

can have important consequences for party policy positioning.

\section{Measures and Model Specification}

To measure party policy positions over time, we employ estimates from the Comparative Manifesto Project (CMP). These estimates are based on analyses of the election policy manifestos of the significant political parties in 25 democracies in the postwar period and provide the only longitudinal and crossnational estimates of party policies for the time period and countries under investigation. In the CMP framework coders determine parties' policy positions via content analysis of election programmes (Budge et al. 2001). Individual coders isolate "quasisentences" in a party's policy program and pair them with policy categories (e.g., education, defense, law and order, morality, etc.) using a preestablished, common classification scheme. The classification scheme is made up of 56 categories and the percentages of each category provide the basis for estimating the policy priorities of a party. ${ }^{14}$ The Left-Right

\footnotetext{
${ }^{14}$ For a more thorough description of the coding process, see Appendix 2 in Budge et al. (2001).
}

ideological scores for parties' policy programmes range from -100 (extreme left) to +100 (extreme right). These CMP measures are generally consistent with those derived using alternative methods for locating parties, such as expert placements, citizen

\section{Figure 1 Ideological Bias in European Electorates, 1973-2002}

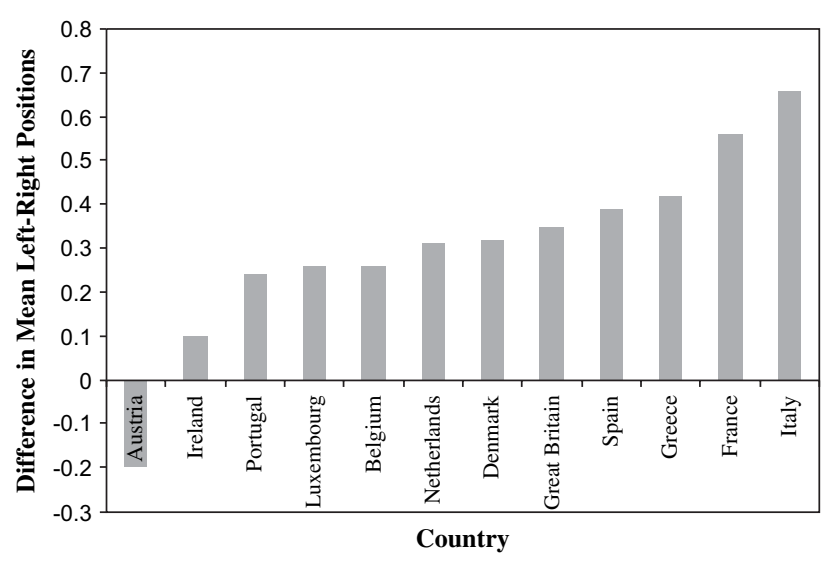

Notes: Columns report the mean self-placements of non-opinion leaders minus opinion leaders' mean self-placements, on a 1-10 Left-Right scale. Positive values indicate that non-opinion leaders are, on average, more right-wing than opinion leaders. Based on difference of means tests, all of the differences are statistically significant at the .01 level, except for Ireland which is statistically significant at the .05 level. 
perceptions of parties' positions, and parliamentary voting analyses (see Hearl 2001; Laver, Benoit, and Garry 2003; McDonald and Mendes 2001). As discussed below, our dependent variable is the change in the focal party's Left-Right position between the previous and the current election.

Our key independent variables are the changes in the mean Left-Right self-placements of the opinion leaders in the country, as well as the mean changes for other voters in the country, between the year of the current election and the year of the previous election (as discussed below we also include lagged versions of these variables). Our focus on party responsiveness to the mean voter position seems appropriate given that our empirical focus is on large, mainstream parties (i.e., Social Democratic, Labor, Liberal, Conservative, and Christian Democratic parties) who typically compete for the support of moderate voters, as opposed to smaller, "niche" parties (such as Communist, Green, and radical right parties) whose more ideological clienteles typically come from the wings of the policy spectrum. Our focus on the mean voter position is consistent with previous research on European party positioning by McDonald and Budge (2005) and Adams et al. (2004, 2006); in particular, the latter set of scholars report evidence that mainstream partiesbut not niche parties - are responsive to shifts in the mean voter position.

We specify a multivariate regression model in order to test the Opinion Leaders Hypothesis ( $\mathrm{H} 1)$ and the Lagged Party Response Hypothesis (H2). This Basic Specification is:

$$
\begin{aligned}
\text { Party shift }(t)= & \mathrm{b}_{1}+\mathrm{b}_{2}[\text { party shift }(t-1)] \\
& +\mathrm{b}_{3}[\text { opinion leader shift }(t)] \\
& +\mathrm{b}_{4}[\text { opinion leader shift }(t-1)] \\
& +\mathrm{b}_{5}[\text { other voters shift }(t)] \\
& +\mathrm{b}_{6}[\text { other voters shift }(t-1)],
\end{aligned}
$$

where

Party shift $(t)=$ the change in the party's LeftRight position in the current election $t$ compared to its position in the previous election $(t-1)$, based on the CMP codings of the party's election manifestos. Similarly, [Party shift $(t-1)]$ is the difference in the CMP Left-Right estimates of the party's position in election $(t-1)$ and election $(t-2)$.

Opinion leader shift $(t)=$ the change in the mean Left-Right self-placements of the opinion leaders in the country between the year of the current election $t$ and the year of the previous election $(t-1)$, based on the Eurobarometer data. Similarly, [Opinion leader shift $(t-1)]$ is the change in the mean LeftRight self-placements of the opinion leaders between the years of election $(t-1)$ and election $(t-2)$.

Other voters shift $(t)=$ the change in the mean Left-Right self-placements for the remaining respondents (i.e., nonopinion leaders) in the country, between the year of the current election $t$ and the year of the previous election $(t-1)$. Similarly, [Other voters shift $(t-1)]$ is the change in the mean LeftRight self-placement of these voters between the years of election $(t-1)$ and election $(t-2)$.

The dependent variable, [Party shift $(t)]$, is constructed so that positive scores denote that the party has shifted to the right since the last election, while negative scores denote leftward shifts. The key independent variables, [opinion leader shift $(t)$ ] and [other voters shift $(t)$ ] (as well as the lagged versions of these variables), are similarly constructed. We note that we define the [Party shift $(t)]$ variable in terms of parties' Left-Right shifts between the year of the current election and the year of the previous election, for the pragmatic reason that our CMP-based measures of party positioning are available only for election years. The public opinion shift variables are similarly defined.

The Opinion Leaders Hypothesis ( $\mathrm{H} 1)$ posits that parties are more responsive to opinion leaders than to other voters in the electorate. This hypothesis is supported to the extent that the estimated coefficient on the [opinion leader shift $(t)$ ] variable (coefficient $b_{3}$ in equation 1) is significantly larger than the estimate on the [other voters shift $(t)$ ] variable (coefficient $b_{5}$ in equation 1). Similarly, the Lagged Party Response Hypothesis $\left(\mathrm{H}_{2}\right)$, that parties are more responsive to lagged shifts in opinion leaders' policy beliefs than to lagged shifts in other voters' beliefs, is supported if the coefficient estimate on the [opinion leader shift $(t-1)$ ] variable (coefficient $\mathrm{b}_{4}$ in equation 1 ) is significantly larger than the estimate on the [other voters shift $(t-1)$ ] variable (coefficient $\mathrm{b}_{6}$ in equation 1 ). Finally, if the coefficient estimates on the [opinion leader shift $(t)$ ] and [opinion leader shift $(t-1)$ ] variables are positive and statistically significant, this will provide evidence that parties are responsive in absolute terms to shifts in opinion leaders' policy beliefs.

Our coefficient estimate on the [opinion leader shift $(t-1)]$ variable is important for another reason: namely, to the extent that we estimate a positive and statistically significant coefficient on this lagged variable, this implies that the association we observe between party shifts at the current time period and opinion leaders' policy shifts at the previous time 
period signifies a representation process whereby parties adjust their positions in response to opinion leaders' policy preferences, rather than a persuasion process in which parties persuade opinion leaders to shift their positions. For if we observe that parties shift their policies in the same direction that opinion leaders shifted their policy beliefs at an earlier time period, we can rule out the possibility that the parties' policy shifts caused the preceding public opinion shift.

Finally, we note that our statistical tests constitute a very conservative approach to evaluating our hypotheses on parties' disproportionate responsiveness to opinion leaders, because in these analyses we do not adjust for the fact that, in the Eurobarometer data, other voters greatly outnumber opinion leaders in every country in our study (see Appendix B). Therefore our tests are biased against finding support for our hypotheses, and hence if we conclude that parties are disproportionately responsive to opinion leaders even when we do not adjust for the comparatively small size of this subconstituency, then this conclusion certainly extends to analyses that control for size effects. On this basis we proceed.

We note that equation (1) includes a control variable, [party shift $(t-1)$ ], which denotes the party's Left-Right shift between election $(t-2)$ and election $(t-1)$. We control for this variable for both theoretical and practical reasons. Theoretically, previous work by Budge (1994) and by Adams (2001) presents arguments that party elites have electoral incentives to shift their party's policies in the opposite direction from their shifts in the previous election. ${ }^{15}$ Practically, controlling for this variable eliminates autocorrelation which is otherwise present in the data.

\footnotetext{
${ }^{15}$ Budge, who argues that party elites may pursue this strategy of "policy alternation" because they recognize the need to satisfy both the moderate and the radical wings of their parties, finds empirical support for the alternation hypothesis in his analysis of CMP data from 20 postwar democracies. Adams, meanwhile, develops a spatial model in which voters are moved by a combination of policy distance and nonpolicy considerations and concludes that voters' nonpolicy-related attachments (such as party identification) can give political parties electoral incentives to shift their policies back and forth over time, thereby creating a pattern that resembles Budge's alternation model. In addition, we note that even if parties' "true" policy positions are stable over time, to the extent that the CMP's estimates of these positions contain measurement error, such errors can generate patterns on party positioning that support the policy alternation model.
}

\section{Results}

The time period for our study extends from 1973 (the first year for which the Eurobarometer data is available) to 2002 (the last year for which the Mannheim trend file compiles the public opinion data). Our analyses encompass the party systems in the 12 countries for which Eurobarometer data on respondents' Left-Right self-placements is available: Austria, Belgium, Denmark, France, Britain, Greece, Ireland, Italy, Luxembourg, the Netherlands, Portugal, and Spain. ${ }^{16}$ We analyze all the mainstream parties in these twelve countries that Budge et al. (2001) judged as politically significant. ${ }^{17}$ Appendix A lists the countries, interelection periods, and parties that we include in the empirical analyses, as well as the mean Left-Right positions of each party's supporters and the proportions of these supporters who were classified as opinion leaders. ${ }^{18}$ Appendix B presents the computed interelection Left-Right shifts for opinion leaders and for other voters in each country, as well as proportions of respondents in each country who were classified as opinion leaders.

\section{Estimating the Parameters of the Basic Specification}

We turn next to estimating the parameters of equation (1). Our data set contains 181 observations of 50 parties' ideological shifts observed over 70 elections in 12 countries, and should thus be regarded as time-series cross-sectional data. While autocorrelation is not an issue for this specification, several other OLS assumptions are often violated in the context of panel and time-series cross-sectional data structures like ours, which can result in biased and inconsistent standard errors. Of these assumptions,

\footnotetext{
${ }^{16}$ We note that the Eurobarometer data for Greece and Spain are not available until these countries joined the European Community in 1981 and 1986, respectively.

${ }^{17}$ That is, we include as our cases all parties that are pictured in the country-by-country graphs of party positions that are published in Chapter 1 in Budge et al. (2001). We viewed a party's inclusion in these graphs as prima facie evidence that these authors judged the party as politically significant. In fact, most of the omitted parties are very small, typically receiving less than $3 \%$ of the national vote.

${ }^{18}$ Party supporters are identified using the "vote intention" item that has been placed consistently on Eurobarometer surveys since 1973. Specifically, the vote intention question asks respondents, "If there were a 'general election' tomorrow, which party would you support?"
} 
we should be concerned about heteroskedasticity and within-country contemporaneous correlation of the errors (Beck and Katz 1995). Accordingly, we report standard errors that are clustered by country-election year, which are robust to both correlation within country-election cycles and heteroskedasticity. Our analysis includes the Left-Right shifts of every party that the CMP classified as belonging to the Socialist, Social Democratic, Liberal, Christian Democratic, or Conservative party families ${ }^{19}$-i.e., the set of party families that constitute the population of mainstream parties, according to previous researchers (e.g., Adams et al. 2006; Meguid 2005).

Column 1 in Table 3 presents the results from estimating the parameters of the basic specification. The coefficient estimate on the [party shift $(t-1)$ ] variable is negative and statistically significant, which is consistent with the theoretical arguments of Budge (1994) and Adams (2001), that parties tend to shift their positions in the opposite direction from their shifts in the previous interelection period. With respect to our key hypotheses, we find statistically significant evidence that parties respond to opinion leaders' current and lagged Left-Right shifts: specifically, the parameter estimate on the [opinion leader shift $(t)]$ variable, +10.70 , and the estimate on the [opinion leader shift $(t-1)$ ] variable, +7.14 , are both positive and statistically significant. Furthermore, the magnitudes of these estimates suggest that these effects are substantively significant: the coefficients suggest that when opinion leaders' mean Left-Right self-placements shift by 0.5 units along the $1-10$ Eurobarometer Left-Right scale during the interelection period, which represents the interquartile range of our opinion leader shift data, then parties' LeftRight positions tend to shift by more than five units in the same direction along the 200-point CMP LeftRight scale during the current interelection period, and to shift more than three additional units in the same direction during the subsequent interelection period - i.e., an 0.5-unit opinion leader shift along the 1-10 Eurobarometer scale is predicted to induce an overall shift of more than eight units by political parties, along the 200-point CMP scale. This is a considerable shift, given that the interquartile range of the observed party shifts is only 17 units, i.e., an 0.5 -unit opinion leader shift is predicted to motivate corresponding party shifts equivalent to nearly half the central spread of the party shift data. Thus political parties appear highly responsive to opinion

\footnotetext{
${ }^{19}$ See Appendix A in Budge et al. (2001) for a discussion of this classification system.
}

leaders' viewpoints, even though opinion leaders comprise only a small fraction of the electorates of the countries included in our study.

By contrast, we find no evidence that parties' Left-Right shifts track the Left-Right shifts of other voters in the electorate: the coefficient estimates on the [other voters shift $(t)]$ variable and the [other voters shift $(t-1)]$ variable are actually negative, and in fact the estimate on the [other voters shift $(t-1)$ ] variable is negative and statistically significant. We certainly do not make the nonsensical inference that parties deliberately shift their positions in opposition to these voters' Left-Right shifts. However, these parameter estimates are such that we can reject, at conventional levels of statistical significance, the proposition that political parties exhibit positive and substantively significant responses to rank-and-file voters' shifts: the upper bound on the $95 \%$ confidence interval for the [other voters shift $(t)$ ] coefficient is about 6.0 , a value that would imply that, ceterus paribus, parties shift their Left-Right positions by less than two units on the 200-point CMP scale in response to a 0.29 unit shift by these voters on the 1-10 Eurobarometer Left-Right scale (the interquartile range of our "other voters" shift data). And, the upper bound on the 95\% confidence interval for the [other voters shift $(t-1)]$ coefficient is actually negative, indicating that we can reject the proposition that parties exhibit any positive policy response to these voters' lagged shifts. Thus political parties appear unresponsive to rank-and-file voters' collective preferences, despite the fact that these voters constitute the overwhelming majority of the electorate in each country in our study.

The bottom two rows in Table 3 present the difference in parties' estimated responsiveness to the policy shifts of opinion leaders versus their response to other voters, along with the conditional standard errors associated with these estimates. ${ }^{20}$ The estimates reported in column 1, for the basic specification, provide statistically significant support for both of our hypotheses: the estimate on public opinion shifts in the current election supports the Opinion Leaders Hypothesis ( $\mathrm{H} 1)$, that parties are more responsive to

\footnotetext{
${ }^{20}$ That is, the responsiveness gap for opinion leaders versus other voters is defined as the difference between the parameter estimate on the [opinion leader shift $(t)$ ] variable (coefficient $b_{3}$ in equation 1) and the estimate on the [other voter shift $(t)]$ variable (coefficient $b_{5}$ in equation 1 ). The conditional standard error of this difference is given by s.e. $\left(b_{3}-b_{5}\right)=$ $\sqrt{\operatorname{var}\left(b_{3}\right)+\operatorname{var}\left(b_{5}\right)+2 \times \operatorname{cov}\left(b_{3}, b_{5}\right)}$ (see Brambor, Clark, and Golder 2006). The responsiveness gap for the lagged shifts of opinion leaders versus other voters is similarly defined.
} 
Table 3 Explaining Parties' Policy Shifts

\begin{tabular}{|c|c|c|c|c|}
\hline & $\begin{array}{c}\text { Basic } \\
\text { specification (1) }\end{array}$ & $\begin{array}{l}\text { Past election } \\
\text { results (2) }\end{array}$ & $\begin{array}{c}\text { Party } \\
\text { moderation (3) }\end{array}$ & $\begin{array}{l}\text { Fully-specified } \\
\text { model (4) }\end{array}$ \\
\hline Opinion leader shift $(t)$ & $10.70^{\star \star}(4.64)$ & $11.44^{\star \star \star}(4.72)$ & $10.81^{\star *}(4.67)$ & $8.18^{\star \star}(4.84)$ \\
\hline Opinion leader shift $(t-1)$ & $7.14^{\star}(4.78)$ & $7.07^{\star}(4.58)$ & $7.26^{\star}(4.79)$ & $9.67^{\star \star}(4.70)$ \\
\hline Other voters shift $(t)$ & $-8.33(8.77)$ & $-8.89(8.71)$ & $-8.47(8.83)$ & $-13.35^{\star}(9.56)$ \\
\hline Other voters shift $(t-1)$ & $-13.90^{\star *}(6.96)$ & $-13.29^{\star *}(7.02)$ & $-13.88^{\star \star}(6.92)$ & $-18.33^{\star \star \star}(6.85)$ \\
\hline Party shift $(t-1)$ & $-.30^{\star \star \star}(.06)$ & $-.30^{\star * \star}(.06)$ & $-.30^{\star * \star}(.05)$ & $-.40^{\star * \star}(.06)$ \\
\hline $\begin{array}{l}\text { party shift }(t-1) \times \text { vote } \\
\quad \text { change }(t-1)\end{array}$ & & $.020^{\star *}(.012)$ & & $.020^{*}(.013)$ \\
\hline vote change $(t-1)$ & & $-.19(.25)$ & & $-.11(.24)$ \\
\hline party ideology & & & $1.54^{\star}(0.97)$ & $1.66^{\star}(1.01)$ \\
\hline Intercept & $-1.43(1.64)$ & $-1.48(1.61)$ & $-1.28(1.64)$ & - \\
\hline $\mathrm{N}$ & 181 & 181 & 181 & 181 \\
\hline Adjusted $\mathrm{R}^{2}$ & .177 & .192 & .184 & .282 \\
\hline $\begin{array}{l}\text { Opinion leaders vs. other } \\
\text { voters responsiveness gap, } \\
\text { current election }\end{array}$ & $19.03^{\star}(11.84)$ & $20.32^{\star \star}(11.83)$ & $19.27^{\star}(11.91)$ & $21.53^{\star \star}(11.93)$ \\
\hline $\begin{array}{l}\text { Opinion leaders vs. other } \\
\text { voters responsiveness gap, } \\
\text { previous election }\end{array}$ & $21.04^{\star \star}(10.35)$ & $20.37^{\star \star}(10.17)$ & $21.14^{\star \star}(10.28)$ & $28.01^{\star \star *}(9.57)$ \\
\hline
\end{tabular}

Notes: ${ }^{*} \mathrm{p}<.10,{ }^{* *} \mathrm{p}<.05,{ }^{* *} \mathrm{p}<.01$, one-tailed tests. The table reports estimated coefficients and robust standard errors (in parentheses) clustered by election. The dependent variable is the change in the party's Left-Right position between the current election and the previous election. The definitions of the independent variables are given in the text. The country-specific intercepts for the Fully-specified model (column 4) are not shown.

the current ideological shifts of opinion leaders than to the current shifts of other members of the electorate. And the estimate on public opinion shifts in the previous election supports the Lagged Party Response Hypothesis (H2), that parties are disproportionately responsive to opinion leaders' lagged policy shifts.

\section{Sensitivity Analyses}

Columns $2-4$ in Table 3 report parameter estimates for pooled data analyses that control for additional factors that plausibly influence parties' policy positions, including the effects of past election results, party system convergence, and unobserved differences between countries.

Past election results. Column 2 reports estimates for a Past Election Results model, which is identical to the basic model except that we control for the possibility that parties adjust their Left-Right positions in response to the outcome of the previous election. Specifically, building on Budge's (1994) empirical finding that parties tend to shift their policies in the same direction as the last time if they gained votes at the previous election, and in the opposite direction if they lost votes (see also Adams et al. 2004; Somer-Topcu 2008), we incorporate a variable [vote change $(t-1)$ ] that denotes the party's vote gain or loss at the previous election, and the variable [vote change $(t-1) \times$ party shift $(t-1)]$ that interacts the vote change variable with the party's Left-Right shift at the previous election. A positive coefficient estimate on this interactive variable will indicate that parties tend to shift their positions in the same direction as their previous policy shift if they gained votes at the previous election and in the opposite direction if they lost votes. The parameter estimate on this variable that we report in column 2 is indeed positive and statistically significant, which supports Budge's arguments. More important for our purposes, the parameter estimates on the policy shifts of opinion leaders and other voters continue to support the Opinion Leaders Hypothesis (H1) and the Lagged Party Response Hypothesis (H2).

Party system convergence. Previous studies by Adams and Somer-Topcu (forthcoming), Ezrow (2007), and Keman and Pennings (2006) report results suggesting that parties tend to moderate their Left-Right positions over time, i.e., left-wing parties tend to shift to the right while right-wing parties shift leftward. To evaluate this hypothesis, we estimated a model that was identical to the basic model except that we incorporated a [party ideology] variable that was scored at -1 for left-wing parties, +1 for 
right-wing parties, and zero for centrist parties. $^{21}$ Column 3 of Table 3 reports the parameter estimates for this Party Moderation model. The estimated coefficient on the [party ideology] variable is positive and significant, which supports the hypothesis that the left-wing parties in our study tended to shift towards the right while the right-wing parties shifted leftward. However, inclusion of this variable does not alter our substantive conclusions: the parameter estimates for this model continue to support hypotheses $\mathrm{H} 1$ and $\mathrm{H} 2$.

\section{A fully specified model with country-specific} effects. Column 4 in Table 3 reports the parameter estimates for a Fully Specified Model, which controls for both past election results and party system convergence and that also includes country-specific intercepts in order to control for the possibility that unobserved differences between countries are driving our results. The coefficient estimates for this model continue to support $\mathrm{H} 1$ and $\mathrm{H} 2$.

Effects of the differences in subconstituency shifts. Next, we reestimated our models using the difference between opinion leaders' shifts and other voters' shifts as our key independent variables, i.e., these variables were [opinion leader shift $(t)$ - other voters shift $(t)$ ], and [opinion leader shift $(t-1)$ - other voters shift $(t-1)]$. These estimates, which purge the model of collinearity between opinion leaders' shifts and other voters' shifts $(\mathrm{r}=.58)$, are reported in Table 4. The coefficient estimates on the key independent variables are positive and statistically significant, indicating that parties are more responsive to opinion leaders' (current and lagged) ideological shifts than to other voters' shifts. These results again support our hypotheses.

Additional analyses. Finally, we conducted two additional robustness checks (the results of which are available upon request). ${ }^{22}$ First, we reestimated the basic model using actual party positions (rather than changes in parties' positions) as the dependent variable and obtained results that supported substantive conclusions identical to those using our original dependent variable. Next we explored the statistical effects of possible measurement error in our key

\footnotetext{
${ }^{21}$ We defined parties as left-wing if the CMP classified the party as being a member of the Social Democratic party family, while right-wing parties were those that the CMP classified as belonging to the Conservative or Christian Democratic party families. Parties were defined as centrist if they were classified as members of the Liberal party family. The parties' family designations are reported in Appendix A.

${ }^{22}$ We thank two anonymous referees for raising the points that we address in this paragraph.
}

independent variables, namely the Left-Right shifts of opinion leaders and of other voters. ${ }^{23}$ To address this issue we conducted "errors in variables" analyses, in which the analyst can specify the degree of reliability of the observed values of the independent variables. We analyzed the effects of varying degrees of measurement error, including the effects of differential measurement error where our measures of opinion leaders' Left-Right shifts were specified as being more (or less) reliable than our measures of other voters' shifts. These analyses supported substantive conclusions that were identical to those we report above. ${ }^{24}$

In toto, we find consistent evidence in support of the Opinion Leaders Hypothesis, that mainstream parties are more responsive to the ideological shifts of opinion leaders than to the ideological shifts of other voters in the electorate, and for the Lagged Party Response Hypothesis, that parties are also disproportionately responsive to opinion leaders' lagged ideological shifts. This latter finding is important because while the observed positive association between parties' and opinion leaders' current policy shifts may arise either because parties respond to opinion leaders or because parties persuade opinion leaders to change their policy preferences, the positive association between party shifts and opinion leaders' lagged shifts cannot be due to parties persuading opinion leaders. Hence we conclude that parties respond to opinion leaders' viewpoints. By contrast, we find no evidence that parties respond positively to shifts in rank-and-file voters' preferences, despite the fact that this constituency comprises the overwhelming majority of the electorate in every country in our study.

\footnotetext{
${ }^{23}$ Given that our measurements of these variables are based on moderately sized voter surveys (roughly 250 opinion leaders and 1,700 other voters per election year), and, furthermore, that individual respondents' Left-Right self-placements may themselves contain measurement error (see, e.g., Converse 1964; Zaller 1992), it is plausible that our measures of Left-Right shifts by opinion leaders and other voters contain considerable error.

${ }^{24} \mathrm{We}$ note that we conducted an additional set of sensitivity analyses designed to estimate party responsiveness to two alternative sets of subconstituencies: namely highly educated voters versus other voters and affluent voters versus other voters. Our reasoning was that, given that the opinion leaders in our study were (modestly) more affluent and more educated than other voters (see footnote 12), party responsiveness to the opinion leaders subconstituency might arise because of this subconstituency's greater affluence and education, rather than because parties respond to opinion leaders per se. These analyses, which are available upon request, do not reveal evidence of disproportionate responsiveness to the affluent and the highly educated.
} 
Table 4 Explaining Parties' Policy Shifts, Differenced Variables

\begin{tabular}{|c|c|c|c|c|}
\hline & $\begin{array}{c}\text { Basic } \\
\text { specification (1) }\end{array}$ & $\begin{array}{l}\text { Past election } \\
\text { results (2) }\end{array}$ & $\begin{array}{c}\text { Party } \\
\text { moderation (3) }\end{array}$ & $\begin{array}{l}\text { Fully-specified } \\
\text { model (4) }\end{array}$ \\
\hline $\begin{array}{l}\text { Opinion leader shift }(t) \\
\quad \text { - Other voters shift }(t)\end{array}$ & $10.44^{\star *}(4.94)$ & $11.19^{* *}(4.96)$ & $10.55^{\star \star}(4.96)$ & $8.83^{\star \star}(5.21)$ \\
\hline $\begin{array}{l}\text { Opinion leader shift }(t-1) \\
\quad \text { - Other voters shift }(t-1)\end{array}$ & $8.47^{\star \star}(4.81)$ & $8.31^{\star \star}(4.64)$ & $8.57^{\star \star}(4.79)$ & $11.29^{\star \star}(4.40)$ \\
\hline $\begin{array}{l}\text { Party shift }(t-1) \\
\text { party shift }(t-1) \times \text { vote } \\
\quad \text { change }(t-1)\end{array}$ & $-.31^{* * *}(.07)$ & $\begin{array}{r}-.32^{\star * *}(.07) \\
.021^{\star}(.012)\end{array}$ & $-.32^{\star * *}(.07)$ & $\begin{array}{r}-.41^{\star * *}(.07) \\
.020^{\star}(.013)\end{array}$ \\
\hline vote change $(t-1)$ & & $-.19(.26)$ & & $-.10(.25)$ \\
\hline party ideology & & & $1.58^{\star}(0.98)$ & $1.70^{\star}(1.00)$ \\
\hline Intercept & $-1.07(1.42)$ & $-1.17(1.41)$ & $-1.03(1.41)$ & \\
\hline $\mathrm{N}$ & 181 & 181 & 181 & 181 \\
\hline Adjusted $\mathrm{R}^{2}$ & .165 & .182 & .174 & .270 \\
\hline
\end{tabular}

Notes: ${ }^{\star} \mathrm{p}<.10,{ }^{\star *} \mathrm{p}<.05,{ }^{* *} \mathrm{p}<.01$, one-tailed tests. The table reports estimated coefficients and robust standard errors (in parentheses) clustered by election. The dependent variable is the change in the party's Left-Right position between the current election and the previous election. The definitions of the independent variables are given in the text. The country-specific intercepts for the Fully-specified model (column 4) are not shown.

\section{Conclusion}

We have reported empirical analyses of data from 12 Western European democracies on the linkages between mainstream parties' Left-Right positions and public opinion. Basing our computations on the Comparative Manifesto Project's codings of parties' Left-Right positions, and the Eurobarometer surveys of citizens' ideological self-placements, we conclude that mainstream parties are more responsive to the current and lagged ideological shifts of opinion leaders than to the ideological shifts of other voters in the electorate. These findings on citizen-elite policy linkages in Western Europe extend the work of Gilens (2005), Griffin and Newman (2005), Bartels (2005), and Highton (2006), who find that American political elites respond disproportionately to the affluent, the well-educated, and the politically involved.

Our findings are significant for political representation, for understanding parties' internal policymaking dynamics, and for spatial modeling. While recent theoretical and empirical studies on Western Europe suggest that the type of party matters for political representation (see Adams et al. 2006; Ezrow 2008; Meguid 2005, 2008), our findings suggest that the type of voter is also crucial for understanding the policy linkages between citizens and elites.

Our finding of representational inequality is significant because, as we have shown, opinion leaders' political viewpoints are substantially to the left of the rest of the electorate in every country in our study (except Austria). This suggests that political elites' disproportionate responsiveness to opinion leaders' views is substantively important, in that it motivates parties to offer more left-wing policy programmes than they would otherwise present. Thus to the extent that governing parties experience pressure to fulfill their preelection policy promises, the form of representational inequality we identify plausibly furthers left-wing parties' policy objectives. In addition, we emphasize that our conclusions on party responsiveness to electoral subconstituencies do not rule out the possibility that organized interest groups-such as the church, trade unions, and business interestssignificantly influence parties' policy programmes (see, e.g., Kalyvas 1994; Kitschelt 1994; Poguntke 2002).

Our finding of parties' lagged policy responses to opinion leaders' viewpoints enhances our understanding of mass-elite policy linkages, and it also supports the perspective advanced in recent computational modeling studies by Kollman, Miller, and Page (1992), Laver (2005), and Fowler and Laver (2008). These studies explore party policy dynamics in situations where parties' strategies during the current time period depend on events in preceding time periods, an approach that fits with our finding of lagged party responsiveness.

In future research we hope to parse out the causal processes that underpin our finding of representational inequality in Western European party systems. We have shown that compared to rank-and-file voters, opinion leaders are more likely to report holding ideological positions, to recognize parties' 
positions, and to participate in politics by voting or via formal party membership. These findings support the communication, selection, and office-seeking processes we have outlined, that motivate our arguments that parties will be disproportionately responsive to opinion leaders. However we have not analyzed how each process mediates party responsiveness. In addition, our finding that parties respond to opinion leaders' current and lagged policy shifts raises the question, do some types of parties update their policies more quickly than others, and if so, which parties? It would also be interesting to extend our focus to determine whether party elites, when they weigh the views of their supporters, attach disproportionate weight to supporters who are opinion leaders as opposed to other supporters (see Dalton 1985; Ezrow et al. 2007). Finally, we hope to eventually extend our research on parties' preelection policy programmes to consider whether opinion leaders' viewpoints also disproportionately influence government policy outputs.

While our objective is to describe how representation is occurring (or not occurring), the normative implications of our findings are quite striking. On the one hand, democratic theory suggests that parties should articulate the policy preferences of citizens equally. On the other hand some may argue that it is natural for certain individuals to disproportionately influence the democratic process, due to the disproportionate time and energy that these individuals expend on political discussion and persuasion.

We have analyzed here how parties adjust their policy positions in response to public opinion in 12 Western European democracies. We have shown that parties display no tendency to respond positively to the vast majority of the public, namely the constituency of rank-and-file citizens who do not engage regularly in political discussion and persuasion. By contrast parties appear highly responsive to the viewpoints of opinion leaders, i.e., the relatively small subconstituency of citizens that habitually discuss politics and who attempt to persuade others on political issues.

\section{Acknowledgments}

Both authors contributed equally to the paper. Earlier versions were presented at the 2007 annual meeting of the Midwest Political Science Association and at the 2007 "Macro Polity" panel of the meetings of the European Consortium for Political Research in Pisa, Italy. We thank John Bartle, Marty Gilens, Kristian
Gleditsch, John Griffin, Cindy Kam, Thomas Pluemper, Jim Stimson, and three anonymous referees for valuable comments, and we thank Zeynep Somer-Topcu for invaluable research assistance. All remaining errors are the authors' sole responsibility.

Manuscript submitted 15 June 2007

Manuscript accepted for publication 2 March 2008

\section{References}

Adams, James. 2001. Party Competition and Responsible Party Government: A Theory of Spatial Competition Based Upon Insights from Behavioral Voting Research. Ann Arbor: University of Michigan Press.

Adams, James, Michael Clark, Lawrence Ezrow, and Garrett Glasgow. 2004. "Understanding Change and Stability in Party Ideologies: Do Parties Respond to Public Opinion or to Past Election Results?" British Journal of Political Science 34 (4): 589-610.

Adams, James, Michael Clark, Lawrence Ezrow, and Garrett Glasgow. 2006. "Are Niche Parties Fundamentally Different from Mainstream Parties? The Causes and Electoral Consequences of Western European Parties' Policy Shifts, 19761998." American Journal of Political Science 50 (3): 513-29.

Adams, James, Samuel Merrill, III, and Bernard Grofman. 2005. A Unified Theory of Party Competition: A Cross-National Analysis Integrating Spatial and Behavioral Factors. Cambridge: Cambridge University Press.

Adams, James, and Zeynep Somer-Topcu. Forthcoming. "Do Parties Adjust Their Policies in Response to Rival Parties' Policy Shifts? Spatial Theory and the Dynamics of Party Competition in Twenty-Five Postwar Democracies." British Journal of Political Science.

Bartels, Larry M. 2005. "Economic Inequality and Political Representation.” Typescript. Princeton University.

Beck, Nathaniel, and Jonathan Katz. 1995. "What to Do (and Not to Do) with Time-Series Cross-Section Data." American Political Science Review 89 (3): 634-47.

Beck, Nathaniel, and Jonathan Katz. 1996. "Nuisance vs. Substance: Specifying and Estimating Time-Series-Cross-Section Models." Political Analysis 6 (1): 1-36.

Brambor, Thomas, William R. Clark, and Matthew Golder. 2006. "Understanding Interaction Models: Improving Empirical Analyses." Political Analysis 14 (1): 63-82.

Budge, Ian. 1994. "A New Theory of Party Competition: Uncertainty, Ideology, and Policy Equilibria Viewed Comparatively and Temporally." British Journal of Political Science 24 (4): 443-67.

Budge, Ian, Hans-Dieter Klingemann, Andrea Volkens, Judith Bara, and Eric Tanenbaum. 2001. Mapping Policy Preferences: Estimates for Parties, Electors, and Governments 1945-1998. Oxford: Oxford University Press.

Converse, Philip. 1964. "The Nature of Belief Systems in Mass Publics." In Ideology and its Discontents, ed. David Apter. New York: Free Press, 206-61.

Dahl, Robert. 1971. Polyarchy: Participation and Opposition. New Haven, CT: Yale University Press.

Dalton, Russell. 1985. "Political Parties and Political Representation.” Comparative Political Studies 17 (3): 267-99. 
Downs, Anthony. 1957. An Economic Theory of Democracy. New York: Harper and Row.

Erikson, Robert, Michael MacKuen, and James Stimson. 2002. The Macro Polity. Cambridge: Cambridge University Press.

Ezrow, Lawrence. 2007. "The Variance Matters: How Party Systems Represent the Preferences of Voters." Journal of Politics 69 (1): 182-92.

Ezrow, Lawrence. 2008. "On the Inverse Relationship between Votes and Proximity for Niche Parties." European Journal of Political Research 47 (2): 206-20.

Ezrow, Lawrence, Catherine de Vries, Marco Steenbergen, and Erica Edwards. 2007. "Dynamic Representation versus Dynamic Correspondence: Do Parties Respond to the Mean Voter Position or to Their Supporters?" Prepared for presentation at the annual meeting of the Midwest Political Science Association.

Farrell, David M., and Paul Webb. 2000. "Political Parties as Campaign Organizations." In Parties Without Partisans: Political Change in Advanced Industrial Societies, ed. Russell J. Dalton and Martin P. Wattenberg. Oxford: Oxford University Press, 102-28.

Fowler, James, and Michael Laver. 2008. "A Tournament of Party Strategies." Journal of Conflict Resolution 52 (1): 68-92.

Gilens, Martin. 2005. "Inequality and Democratic Responsiveness." Public Opinion Quarterly 69 (5): 778-96.

Griffin, John D., and Brian Newman. 2005. "Are Voters Better Represented?” Journal of Politics 67 (4): 1206-27.

Hearl, Derek J. 2001. "Checking the Party Policy Estimates: Reliability." In Mapping Policy Preferences: Estimates for Parties, Electors, and Governments 1945-1998, ed. Ian Budge, Hans-Dieter Klingemann, Andrea Volkens, Judith Bara, and Eric Tanenbaum, Oxford: Oxford University Press, 111-26.

Highton, Benjamin. 2005. "Whose Opinions Matter? Political Information and the Responsiveness of Elected Officials." Typescript. University of California, Davis.

Huckfeldt, Robert. 2001. "The Social Communication of Political Expertise." American Journal of Political Science 45 (2): 425-38.

Kalyvas, Stathis. 1994. The Rise of Christian Democracy in Europe. Ithaca, NY: Cornell University Press.

Keman, Hans, and Paul Pennings. 2006. "Competition and Coalescence in European Party Systems: Social Democracy and Christian Democracy Moving into the $21^{\text {st }}$ Century." Swiss Political Science Review 12 (2): 95-126.

Kitschelt, Herbert. 1994. The Transformation of European Social Democracy. New York: Cambridge University Press.

Kollman, Kenneth, John Miller, and Scott Page. 1992. "Adaptive Parties in Spatial Elections." American Political Science Review 86 (4): 929-37.

Laver, Michael, Kenneth Benoit, and John Garry. 2003. "Extracting Policy Positions from Political Texts Using Words as Data." American Political Science Review 97 (2): 311-31.

Laver, Michael. 2005. "Policy and the Dynamics of Political Competition." American Political Science Review 99 (2): 263-81.

McDonald, Michael, and Ian Budge. 2005. Elections, Parties, and Democracy: Conferring the Median Mandate. Oxford: Oxford University Press.
McDonald, Michael, and Sylvia Mendes. 2001. "Checking the Party Policy Estimates: Convergent Validity." In Mapping Policy Preferences: Estimates for Parties, Electors, and Governments 1945-1998, ed. Ian Budge, Hans-Dieter Klingemann, Andrea Volkens, Judith Bara, and Eric Tanenbaum, Oxford: Oxford University Press, 127-42.

McDonald, Michael, Sylvia Mendes, and Ian Budge. 2004. "What are Elections For? Conferring the Median Mandate." British Journal of Political Science 34 (1): 1-26.

Meguid, Bonnie. 2005. "Competition between Unequals: The Role of Mainstream Party Strategy in Niche Party Success." American Political Science Review 99 (3): 347-60.

Meguid, Bonnie. 2008. Party Competition between Unequals. Cambridge: Cambridge University Press.

Poguntke, Thomas. 2002. "Party Organization Linkage: Parties without Firm Social Roots?" In Political Parties in the New Europe, ed. Kurt Richard Luther and Ferdinand MullerRommel. New York: Oxford University Press, 43-62.

Sartori, Giovanni. 1968. "Representational Systems." International Encyclopedia of the Social Sciences 13: 470-75.

Scarrow, Susan. 2000. "Parties without Members? Party Organization in a Changing Electoral Environment." In Parties without Partisans: Political Change in Advanced Industrial Societies, ed. Russell J. Dalton and Martin P. Wattenberg. Oxford: Oxford University Press, 79-101.

Schmitt, Herman, and Evi Scholz. The Mannheim Eurobarometer Trend File, 1970-2002 [Computer file]. Prepared by Zentralarchiv fur Empirische Sozialforschung. ICPSR04357-v1. Mannheim, Germany: Mannheimer Zentrum fur Europaische Socialforschung and Zentrum fur Umfragen, Methoden und Analysen [producers], 2005. Cologne, Germany: Zentralarchiv fur Empirische Sozialforschung/Ann Arbor, MI: Inter-university Consortium for Political and Social Research [distributors], 2005-12-06.

Somer-Topcu, Zeynep. 2008. "Timely Decisions: The Effects of Past Election Results on Party Policy Change." Journal of Politics. Forthcoming.

Stimson, James, Michael MacKuen, and Robert Erikson. 1995. "Dynamic Representation." American Political Science Review 89 (3): 543-65.

Verba, Sidney. 2003. "Would the Dream of Political Equality Turn Out to Be a Nightmare?" Perspectives on Politics 1 (4): 663-80.

Zaller, John. 1992. The Nature and Origins of Mass Opinion. Cambridge: Cambridge University Press.

James Adams is a professor of political science, University of California-Davis, Davis CA 95616. Lawrence Ezrow is a lecturer in European Politics, University of Essex, Colchester CO4 3SQ, UK. 
Appendix A List of Countries, Parties, and Party Families Included in the Empirical Analyses

\begin{tabular}{|c|c|c|c|c|c|}
\hline $\begin{array}{l}\text { Country Inter-Election } \\
\text { Period }\end{array}$ & Party & Party Family & $\begin{array}{l}\text { L/R Other } \\
\text { Voters }\end{array}$ & $\begin{array}{l}\text { L/R Opinion } \\
\text { Leaders }\end{array}$ & $\begin{array}{c}\text { Proportion } \\
\text { Opinion Leaders }\end{array}$ \\
\hline \multicolumn{6}{|l|}{ Austria } \\
\hline \multirow[t]{3}{*}{ 1995-99; 1999-2003 } & Austrian Peoples’ Party (ÖVP) & Conservative & 5.67 & 5.93 & .15 \\
\hline & $\begin{array}{l}\text { League of the Independents, later named } \\
\text { Freedom Movement (VdU / FPÖ) }\end{array}$ & Liberal & 6.25 & 6.79 & .19 \\
\hline & Social Democratic Party (SPÖ) & Social Democratic & 4.37 & 4.25 & .15 \\
\hline \multicolumn{6}{|l|}{ Belgium } \\
\hline 1977-78; 1979-81; & Christian Social Party (PSC) & Christian Democratic & 6.58 & 6.58 & .09 \\
\hline 1985-87; 1987-91; & Christian People's Party (CVP) & Christian Democratic & 6.86 & 6.85 & .08 \\
\hline \multirow[t]{5}{*}{ 1991-95; 1995-99 } & Liberal Reformation Party (PRL) & Liberal & 6.53 & 6.90 & .13 \\
\hline & $\begin{array}{l}\text { Liberal Reformation Party - Francophone } \\
\text { Democratic Front (PRL-FDF) }\end{array}$ & Liberal & 6.25 & 6.61 & .09 \\
\hline & Flemish Liberals and Democrats (VLD) & Liberal & 5.82 & 6.12 & .11 \\
\hline & Francophone Socialist Party (PS) & Social Democratic & 3.85 & 3.37 & .10 \\
\hline & Flemish Socialist Party (SP) & Social Democratic & 4.37 & 3.43 & .10 \\
\hline \multicolumn{6}{|l|}{ Denmark } \\
\hline 1977-79; 1979-81; & Conservative People's Party (KF) & Conservative & 7.41 & 7.66 & .14 \\
\hline 1981-84; 1984-87; & Radical Party (RV) & Liberal & 5.48 & 5.40 & .18 \\
\hline 1987-88; 1988-90; & Liberals (V) & Liberal & 6.86 & 7.30 & .15 \\
\hline 1990-94; 1994-98; & Social Democratic Party (SD) & Social Democratic & 4.99 & 4.62 & .13 \\
\hline 1998-2001 & Center Democrats (CD) & Social Democratic & 6.28 & 6.44 & .13 \\
\hline \multicolumn{6}{|l|}{ France } \\
\hline 1978-81; 1981-86; & Rally for the Republic (RPR) & Conservative & 7.13 & 7.29 & .13 \\
\hline 1986-88; 1988-93; & Union for French Democracy (UDF) & Conservative & 6.19 & 6.07 & .12 \\
\hline 1993-97; 1997-2002 & Socialist Party (PS) & Social Democratic & 3.72 & 3.19 & .14 \\
\hline \multicolumn{6}{|l|}{ Greece } \\
\hline $1981-85 ; 1985-89$ & New Democracy (ND) & Christian Democratic & 8.14 & 8.21 & .32 \\
\hline $\begin{array}{l}\text { (June); 1989-89 (Nov); } \\
\text { 1989-90; 1990-93; } \\
\text { 1993-1996; 1996-2000 }\end{array}$ & $\begin{array}{l}\text { Panhellenic Socialist Movement } \\
\text { (PASOK) }\end{array}$ & Social Democratic & 4.72 & 4.31 & .34 \\
\hline \multicolumn{6}{|l|}{ Ireland } \\
\hline $1977-81 ; 1981-82$ & Fianna Fail & Conservative & 6.47 & 6.60 & .10 \\
\hline (Feb); 1982-82 (Nov); & Fine Gail & Christian Democratic & 6.25 & 6.37 & .12 \\
\hline 1982-87; 1987-89; & Progressive Democrats (PD) & Liberal & 6.12 & 6.00 & .16 \\
\hline $\begin{array}{l}\text { 1989-92; 1992-97; } \\
1997-2002\end{array}$ & Labour Party (LP) & Social Democratic & 4.81 & 4.26 & .13 \\
\hline
\end{tabular}




\begin{tabular}{|c|c|c|c|c|c|}
\hline $\begin{array}{l}\text { Country Inter-Election } \\
\text { Period }\end{array}$ & Party & Party Family & $\begin{array}{l}\text { L/R Other } \\
\text { Voters }\end{array}$ & $\begin{array}{l}\text { L/R Opinion } \\
\text { Leaders }\end{array}$ & $\begin{array}{c}\text { Proportion } \\
\text { Opinion Leaders }\end{array}$ \\
\hline \multicolumn{6}{|l|}{ Italy } \\
\hline 1976-79; 1979-83; & Go Italy (FI) & Conservative & 7.04 & 7.14 & .16 \\
\hline 1983-87; 1987-92; & Italian People's Party (PPI) & Christian Democratic & 5.33 & 5.39 & .20 \\
\hline 1992-94; 1994-96; & Republican Party (PRI) & Liberal & 5.04 & 4.55 & .14 \\
\hline \multirow[t]{2}{*}{ 1996-2001 } & Italian Democratic Socialist Party (PSDI) & Social Democratic & 4.69 & 4.18 & .14 \\
\hline & Socialist Party (PSI) & Social Democratic & 3.69 & 3.31 & .15 \\
\hline \multicolumn{6}{|l|}{ Luxembourg } \\
\hline \multirow[t]{3}{*}{$\begin{array}{l}\text { 1979-84; 1984-89; } \\
\text { 1989-94; 1994-99 }\end{array}$} & $\begin{array}{l}\text { Christian Social People's Party } \\
\quad \text { (PCS/CSV) }\end{array}$ & Christian Democratic & 6.78 & 6.80 & .16 \\
\hline & $\begin{array}{l}\text { Patriotic and Democratic Group } \\
\quad(\mathrm{PD} / \mathrm{DP})\end{array}$ & Liberal & 5.82 & 5.76 & .20 \\
\hline & Socialist Workers’ Party (POSL/ LSAP) & Social Democratic & 4.35 & 3.71 & .18 \\
\hline \multicolumn{6}{|l|}{ Netherlands } \\
\hline 1977-81; 1981-82; & Christian Democratic Appeal (CDA) & Christian Democratic & 6.65 & 6.67 & .13 \\
\hline $\begin{array}{l}\text { 1982-86; 1986-89; } \\
\text { 1989-94; 1994-98; }\end{array}$ & $\begin{array}{l}\text { People's Party for Freedom and } \\
\text { Democracy (VVD) }\end{array}$ & Liberal & 6.74 & 7.06 & .17 \\
\hline \multirow[t]{2}{*}{ 1998-2002 } & Labour Party (PvdA) & Social Democratic & 3.92 & 3.39 & .15 \\
\hline & Democrats 66 (D’66) & Social Democratic & 4.84 & 4.60 & .12 \\
\hline \multicolumn{6}{|l|}{ Portugal } \\
\hline 1987-91; 1991-95; & Center Social Democrats (CDS/PP) & Conservative & 7.21 & 7.57 & .08 \\
\hline \multirow[t]{2}{*}{ 1995-99 } & Popular Democratic Party (PPD/PSD) & Social Democratic & 6.83 & 6.70 & .08 \\
\hline & Portuguese Socialist Party (PSP) & Social Democratic & 4.55 & 4.24 & .06 \\
\hline \multicolumn{6}{|l|}{ Spain } \\
\hline 1986-89; 1989-93; & Popular Alliance (AP/PP) & Conservative & 6.97 & 7.35 & .08 \\
\hline \multirow[t]{3}{*}{ 1993-96; 1996-2000 } & Convergence and Union (CiU) & Conservative & 5.15 & 5.39 & .08 \\
\hline & Spanish Socialist Workers' Party (PSOE) & Social Democratic & 3.59 & 3.21 & .06 \\
\hline & Center Party (CP) & Liberal & 5.35 & 5.21 & .07 \\
\hline \multicolumn{6}{|l|}{ United Kingdom } \\
\hline 1979-83; 1983-87; & Conservative Party & Conservative & 7.00 & 7.45 & .10 \\
\hline 1987-92; 1992-97; & Liberal Democrats (LD) & Liberal & 5.37 & 5.07 & .11 \\
\hline 1997-2001 & Labour Party & Social Democratic & 4.43 & 3.80 & .14 \\
\hline
\end{tabular}

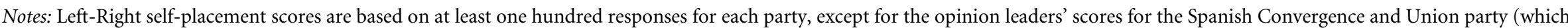

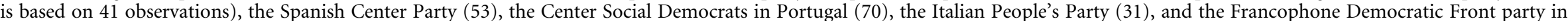

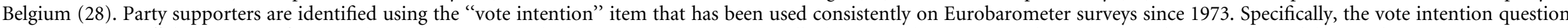

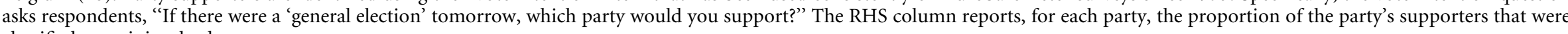
classified as opinion leaders. 
Appendix B Countries, Interelection Periods, and the Left-Right Preference Shifts of Opinion Leaders and Other Voters Included in the Empirical Analyses

\begin{tabular}{|c|c|c|c|c|}
\hline Country & Election cycle & $\begin{array}{c}\text { Left-Right } \\
\text { Shifts of } \\
\text { “Other } \\
\text { Voters" }\end{array}$ & $\begin{array}{c}\text { Left-Right } \\
\text { Shifts of } \\
\text { Opinion } \\
\text { Leaders }\end{array}$ & $\begin{array}{c}\text { Proportion } \\
\text { of Opinion } \\
\text { Leaders }\end{array}$ \\
\hline \multirow[t]{2}{*}{ Austria } & 1995-99 & -0.14 & 0.14 & .129 \\
\hline & 1999-02 & -0.23 & 0.85 & \\
\hline \multirow[t]{7}{*}{ Belgium } & $1977-78$ & 0.14 & 0.42 & .078 \\
\hline & $1978-81$ & -0.43 & -0.31 & \\
\hline & 1981-85 & -0.03 & -0.68 & \\
\hline & 1985-87 & -0.17 & -0.22 & \\
\hline & 1987-91 & 0.00 & 0.58 & \\
\hline & 1991-95 & -0.20 & -0.11 & \\
\hline & 1995-99 & -0.25 & -0.40 & \\
\hline \multirow[t]{9}{*}{ Denmark } & $1977-79$ & 0.20 & 0.39 & .143 \\
\hline & 1979-81 & 0.01 & 0.33 & \\
\hline & $1981-84$ & 0.08 & -0.63 & \\
\hline & $1984-87$ & -0.02 & 0.50 & \\
\hline & 1987-88 & 0.36 & 0.32 & \\
\hline & $1988-90$ & -0.47 & -0.25 & \\
\hline & 1990-94 & -0.07 & 0.37 & \\
\hline & 1994-98 & 0.04 & -0.14 & \\
\hline & 1998-01 & -0.02 & 0.03 & \\
\hline \multirow[t]{7}{*}{ France } & $1973-78$ & -0.16 & -0.13 & .114 \\
\hline & $1978-81$ & -0.14 & 0.19 & \\
\hline & 1981-86 & 0.36 & 0.47 & \\
\hline & $1986-88$ & -0.22 & -0.19 & \\
\hline & 1988-93 & -0.01 & 0.14 & \\
\hline & 1993-97 & -0.23 & -0.13 & \\
\hline & 1997-02 & 0.28 & 1.00 & \\
\hline \multirow[t]{5}{*}{ Great Britain } & 1979-83 & -0.01 & -0.69 & .101 \\
\hline & $1983-87$ & 0.10 & 0.35 & \\
\hline & 1987-92 & -0.27 & -0.36 & \\
\hline & 1992-97 & -0.54 & -0.26 & \\
\hline & 1997-01 & -0.08 & -0.09 & \\
\hline \multirow{6}{*}{ Greece } & 1981-85 & -0.63 & -0.24 & 257 \\
\hline & 1985-89 & 0.37 & 0.83 & \\
\hline & 1989-90 & 0.02 & 0.02 & \\
\hline & 1990-93 & -0.16 & -0.09 & \\
\hline & 1993-96 & -0.09 & 0.09 & \\
\hline & 1996-00 & 0.26 & 0.20 & \\
\hline \multirow[t]{8}{*}{ Ireland } & 1973-77 & 0.10 & 0.29 & .092 \\
\hline & 1977-81 & -0.17 & -0.18 & \\
\hline & $1981-82$ & -0.01 & -0.06 & \\
\hline & $1982-87$ & -0.04 & 0.2 & \\
\hline & 1987-89 & -0.18 & -0.06 & \\
\hline & 1989-92 & -0.44 & -0.24 & \\
\hline & 1992-97 & -0.12 & 0.06 & \\
\hline & 1997-02 & 0.37 & 0.3 & \\
\hline \multirow{3}{*}{ Italy } & $1976-79$ & -0.10 & -0.22 & .130 \\
\hline & 1979-83 & 0.27 & 0.26 & \\
\hline & $1983-87$ & 0.08 & 0.05 & \\
\hline
\end{tabular}


Appendix B (Continued)

\begin{tabular}{|c|c|c|c|c|}
\hline Country & Election cycle & $\begin{array}{l}\text { Left-Right } \\
\text { Shifts of } \\
\text { "Other } \\
\text { Voters" }\end{array}$ & $\begin{array}{c}\text { Left-Right } \\
\text { Shifts of } \\
\text { Opinion } \\
\text { Leaders }\end{array}$ & $\begin{array}{c}\text { Proportion } \\
\text { of Opinion } \\
\text { Leaders }\end{array}$ \\
\hline & 1987-92 & 0.06 & 0.47 & \\
\hline & 1992-94 & 0.26 & 0.07 & \\
\hline & $1994-96$ & -0.06 & 0.43 & \\
\hline & $1996-01$ & 0.35 & 0.32 & \\
\hline \multirow[t]{4}{*}{ Luxembourg } & $1979-84$ & -0.13 & -0.22 & .144 \\
\hline & $1984-89$ & -0.27 & 0.04 & \\
\hline & 1989-94 & -0.37 & 0.06 & \\
\hline & 1994-99 & -0.22 & -0.33 & \\
\hline \multirow[t]{7}{*}{ Netherlands } & $1977-81$ & -0.27 & -0.24 & .131 \\
\hline & $1981-82$ & 0.04 & 0.02 & \\
\hline & $1982-86$ & -0.17 & -0.40 & \\
\hline & $1986-89$ & -0.09 & -0.01 & \\
\hline & 1989-94 & -0.25 & 0.23 & \\
\hline & 1994-98 & 0.09 & -0.29 & \\
\hline & 1998-02 & 0.19 & 0.36 & \\
\hline \multirow[t]{4}{*}{ Portugal } & $1985-87$ & 0.23 & 0.65 & .055 \\
\hline & 1987-91 & -0.29 & -0.28 & \\
\hline & $1991-95$ & -0.24 & -0.15 & \\
\hline & 1995-99 & -0.05 & -0.16 & \\
\hline \multirow[t]{4}{*}{ Spain } & $1986-89$ & -0.45 & 0.08 & .059 \\
\hline & 1989-93 & 0.27 & 0.11 & \\
\hline & 1993-96 & 0.03 & 0.48 & \\
\hline & 1996-00 & 0.17 & -0.03 & \\
\hline
\end{tabular}

Notes: The opinion shift scores for "other voters" and for "opinion leaders" represent the difference between Eurobarometer respondents mean Left-Right self-placements in the year of the current election and their mean self-placements in the year of the previous election, on the 1-10 Left-Right scale. Negative scores denote "Leftward" public opinion shifts, and positive scores denote "Rightward" shifts. The proportions of opinion leaders reported in the RHS column represent the proportions of Eurobarometer respondents from the country that were classified as opinion leaders, averaged over the full set of Eurobarometer surveys administered over the period 1973-2002. 